\title{
Where Were the English? Antoon Van Den Wijngaerde, the Evidence of Visual Culture, and the 1557 Siege of Saint-Quentin
}

\author{
Glyn Redworth
}

In March 1557, King Philip I of England travelled to London to implore his wife, Mary Tudor, to support his war against France. An army of 4,00o English foot soldiers, along with 1,00o cavalry, and over 1,500 military engineers and sappers went over to join him and the bulk of his army in what is today southern Belgium. Meanwhile, an advance party under his cousin, the Duke of Savoy, had besieged the prosperous northern French town of Saint-Quentin. English sappers under military escort arrived ahead of the rest of the English troops to help in the siege. On St Lawrence's Day, 1o August, the duke scored a stunning victory over the French constable, the Duke of Montmorency, as he was trying to relieve the town. The constable and with him the cream of the French nobility were captured. King Philip's army, along with the rest of the English troops,

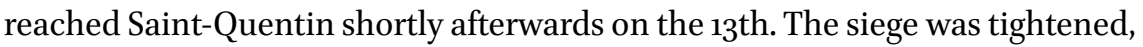
and the town was overrun on 27 August 1557.

'Never children crept more unwillingly to school than the English contingent which joined the Spaniards after the battle of St. Quentin.' ${ }^{1}$ Thus spoke Sir John W. Fortescue, arguably the most influential twentieth-century historian of the British army. He was describing a time when King Philip I of England led an English army into the field against the French in the late summer of 1557. This article will assess largely overlooked visual evidence in order to re-evaluate what remains the prevailing view, barely modified in more recent scholarship, namely that the English arrived late, did little, and went home early.

The 30-year-old King Philip evidently did not realise that he was cutting against the grain of his adopted country's destiny when he took command of an English army. Modern historians have been just as much swept along by a similar assumption - perhaps even the prejudice - that stout Englishmen

1 Fortescue J.W., A History of the British Army, 2nd ed., vol. 1 (London: 1910) 125-126. 
could never have submitted enthusiastically to the will of a foreign monarch. In consequence, scholars are stubbornly mealy-mouthed about the contribution made by English soldiers, sappers, and mounted men-at-arms to the multinational campaign of 1557 . The calamitous loss of Calais early in 1558 certainly played a part in souring historical memory, yet this ignores the fact that, by the time the town succumbed to the French, Philip's English army had long since returned home across the Channel and no Spanish troops were inside its walls.

Scholars persist in latching onto any contemporary criticism of English readiness to fight. This in turn feeds back into an atavistic view that early-modern England had a unique attachment to its sense of national independence, a set of feelings that supposedly meant that the English could never come to terms with being a member of the Habsburgs' European-wide community. Even that most fair-minded of historians, David Loades, damned with faint praise. He conceded that the English contingent had eventually 'done something to redeem their tarnished reputation [...] but it is clear from [the King's] own report [...] that he believed them to have been tardy and negligent.' ${ }^{2}$ John Edwards, in his elegant study of the queen's reign, grants that, although the English arrived too late to take part in the battle around Saint-Quentin, the English were 'very much part of the action', at least in the subsequent siege of the town. ${ }^{3}$ But if both Edwards and Loades acknowledge, almost in passing, that one Spanish officer present at the storming of the town on 27 August recognised that the English fought best of all, ${ }^{4}$ neither historian specifically mentions the English contribution to the capture of the strongly defended fortress-town of Ham. Ham is also ignored by Cliff Davies, who has written the most sensitive account of the whole campaign. His view, though again not wholly without justification, is that the king 'evidently believed that England's most useful contribution in 1557 lay in pioneers and miners for siege operations'. Davies then went

2 Loades D., The Reign of Queen Mary: government, politics and religion 1553-58, 2nd ed. (Abingdon: 2013) 313. Typical of English accounts of the campaign (and atypical of D.M. Loades) is the degree of minor inaccuracy; for instance, on 312, Loades twice indicates that Philip returned from London with his English army, as does John Edwards in his groundbreaking study, Mary I: England's Catholic Queen (London: 2011) 303. Though the diarist, Henry Machyn, has the king departing on the 5 th, Philip probably sailed from Dover on the 6th or even the early hours of 7 May, but even so it would be some weeks before his English army followed him across the Channel. For an excellent account of the willingness of former rebels to display their loyalty by signing up for the king's army, see Adams S., "The Dudley Clientele", in Bernard G.W (ed.), The Tudor Nobility (Manchester: 1992) 247-253.

3 Edwards, MaryI 304.

4 For Juan de Pinedo's letter written during the assault, see below p. 27. 
on to minimise the contribution of the English land forces by remarking that 'far more important was the navy'.

If we examine what was said at the time about the campaign, we see that contemporaries were divided in their assessment of England's involvement. There was undoubtedly heavy criticism from some observers. But to assume that negative comments must outweigh all praise is to normalize an already tainted view of this war. To expect that only an unambiguously decisive and triumphal intervention could indicate the nation's willingness to accept its place within the Habsburg union would only be a further manifestation of English exceptionalism. At one time or another, all the countries fighting for King Philip would receive a degree of censure from those observing the fighting. Nonetheless, if we look first at what English commentators were saying at the time it is evident that they felt a rush of blood to the head when they reported on their compatriots' achievements. The great London diarist, Henry Machyn, wrote that on the night of 3 September an order went out that every church in the capital and up and down the land was 'to sing and make bonfires for the winning of Saint Quintin'. ${ }^{6}$ Another diarist, Charles Wriothesley, periphrastically noted that 'the King laid siege to the town of Saint Quintins by the water of the Somme, and on Friday the 27 of August the town was won by the King with the help of Englishmen: ${ }^{7}$ Holinshed put flesh on the bones in his chronicle. The same passage appears practically unaltered in both the 1577 and 1587 versions and merits quotation at length:

... King Philip with the English army under the government of the earl of Pembroke, and others, came to the siege afore St. Quintins, and so was the siege greatly re-enforced, and on the xxvii of August by the special aid and help of the Englishmen, the town of Saint Quintin was taken. For when the other soldiers after diverse assaults were repulsed and gave over, the English men of a stout courage gave a new onset, by reason whereof the town was taken. And in reward of their well doing, King Philip granted them the sackage of the said town. ${ }^{8}$

5 Davies C.S.L., "England and the French War, 1557-9", in Loach J. - Tittler R. (eds.), The MidTudor Polity, c. 1540-156o (London: 1980) 159-185, here 164.

6 The Diary of H. Machyn, Citizen and Merchant Taylor of London, from AD $155^{\circ}$ to AD 1563, ed. J.G. Nichols (London: 1848) 15o. All quotations from printed works English are modernised.

7 The italics are mine. Wriothesley C., A Chronicle of England during the Reigns of the Tudors, from A.D. 1485 to 1559 , ed. W.D. Hamilton, vol. 2 (London: 1875, 1877) 139.

8 See under the year 1557, in The Holinshed Project at http://english.nsms.ox.ac.uk/holinshed/ (last accessed April 202O). Holinshed adds that this 'sudden short gladness' was quickly replaced by shame at the loss of Calais. 
Holinshed's recollection of English bravery on the day of the siege is thoroughly attested. The anonymous Nuremberg Account of the campaign recorded how the English willingly took the lead in a direct assault on the town's principal and most heavily defended gate, and how, after suffering notable casualties, despite being beaten back, they quickly rallied. ${ }^{9}$

Disapproval of England's contribution is more readily found among Philip's own courtiers. The time it took the English troops to link up with his army was used by the king and those around him to offer one excuse concerning why he arrived too late at the siege of Saint-Quentin to witness the Duke of Savoy's destruction of the French army, in open fields a few kilometres to the south of the town. More pointed were comments made about the English sappers in an exchange between two high-ranking eyewitnesses to the final stages of the siege. One was the $5^{\text {th }}$ Count (and later Duke) of Feria, Philip's chosen interlocutor with Queen Mary during his absences from England. The other was Antoine de Perrenot, Bishop of Arras and later Cardinal Granvelle. ${ }^{10}$ Originally from Franche-Comté, Perrenot was to prove himself time and again no lover of the English. He was also a Jeremiah. His habit of offering logistical and financial advice infuriated the Duke of Savoy, even though the bishop jokingly conceded that war was beyond his job description. ${ }^{11}$ In April 1558, Perrenot laid into the performance of English sappers, contending this was the king's own opinion too. ${ }^{12}$ He reported back that Edward Fiennes - who, as Lord Clinton, had also been present the previous year at Saint-Quentin - acquiesced in the view that the English sappers had neither been properly drilled nor well commanded. The count singled out the English commander, William Herbert, for blame, sarcastically arguing that 'my friend the Earl of Pembroke had managed things very badly all round. ${ }^{13}$

9 "Relation anonyme de la Guerre de 1557 en Picardie", being Pièce Justicative vi in Lemaire E. et al., La Guerre de 1557 en Picardie: bataille de Saint-Laurent, siège de SaintQuentin, prises du Catelet, de Ham, de Chauny et de Noyon (St.-Quentin: 1896) 93; much the same story is told by the notable military commentator, Colonel Lazarus Schwendi, who also participated in the attack and whose account is to be found in the same volume at p. 310, where in his words the English 'sy sich baldt wider gewendt'.

10 For an overview, see Davies, "England and the French War", 163-164. The international context is best surveyed in Rodríguez-Salgado M.J., The Changing Face of Empire: Charles V, Philip II and Habsburg Authority (Cambridge: 1988).

11 'la guerra siendo fuera de mi profesion', Granvelle to Ascarnio Marzo, draft, Brussels 3 July 1557, Real Biblioteca, Madrid [RBM], Ms. II-2549, fol. 48.

12 Granvelle to Feria, Brussels, 7 Apr. 1558, Tyler R. (ed.), Calendar of State Papers Spanish, vol. 13 (London: 1954) $377-378$. The opinion was that at Montreuil and at Hesdin a few years earlier sappers from England had performed exceptionally well.

13 'porq[ue] mi amigo el c[on]de de penbruc se guouerno muy ruin mente en todo', Feria to Granvelle, Greenwich,14 Apr. 1558, RBM, Ms. II-2289, fol. 125 a-d, here c. 
Bishop, count, and king liked to agree that the sappers had done little and badly'.14 Nevertheless, criticism of their contribution needs to be placed in context. It smacks of a political desire to marginalize the Earl of Pembroke (or at least to promote Lord Clinton as the man to represent the king's interests at his wife's court precisely because Clinton, unlike the earl, still believed that Calais might be recaptured). As for leadership at Saint-Quentin, Pembroke may well have been overall commander of the English forces, but the sappers' immediate superior was Sir Richard Lee, who had already proved himself to be a valiant soldier as well as England's best military engineer. As captain-general of the Pioneers, Lee had been accorded the handsome salary of $£_{1}$ a day. ${ }^{15}$ But perhaps the most salient fact is that Perrenot included these reproaches in the very letter that contained the king's insistent demand that a thousand English sappers be urgently recruited to serve him, barely over half a year after their alleged poor showing at Saint-Quentin.

The death toll suffered by English sappers does not fit comfortably with later accusations that they had been slackers. Though barely mentioned if at all in modern accounts, the sappers arrived well ahead of the bulk of the English army, and so they, along with their armed escort, were on site several days before the battle that smashed the French army. To their swift arrival should be added the fact that they worked in exceptionally dangerous conditions. Out of over 1,500 pioneers and 200 miners, 98 sappers died, and 11 miners were recorded as wounded. The mortality rate among the sappers - during a relatively short campaign - was therefore over $6 \%$. Almost 300 more were discharged; if the majority of these were too injured to continue, then the attrition rate might be $20 \%$ or even higher. ${ }^{16}$

The high number of pioneers lost or injured in August and September 1557 does not square with the notion that they contributed little, nor would it suggest that they were reluctant to support a foreign-born king. Their heavy losses chime better with the more positive assessments of the English

14 'el poco y malo que hizieron este año pasado los que Vuestra Magestad tuvo', Feria to Philip, London, 6 June 1558, Kervyn de Lettenhove J.M.B.C. (ed.), Relations politiques des Pays-Bas et de l'Angleterre, vol. 1 (Brussels: 1882) 208-211, here 210. They also agreed that not long before at Thérouanne and Hesdin the performance of English sappers, apparently under a Spanish commander, had been exceptional.

15 British Library, London [BL], Stowe Ms. 571, fol. 86.

16 BL Stowe Ms. 572, fol. 9o. The figures need to be interpreted carefully, not least as sickness was prominent at St.-Quentin, possibly aided by the intense August heat of that year. See also, Davies, 'England and the French War', 166 for his calculations; Paul Hammer, in his Elizabeth's Wars: War, Government and Society in Tudor England, 1544-1604 (Basingstoke: 2003) 49 and passim, suggests the English rate of mortality, largely from sickness, during the campaigns of the late 155 os was high and not reached again till the end of the nineteenth century. 
contribution that were drawn up by fellow soldiers while the fighting was still going on. As we have seen, the attack on the town of Ham, following on almost immediately from the fall of Saint-Quentin, has received little attention at least from English-speaking historians. Situated some 20 kilometres to the south-west, Ham had provided a base for one attempt after another to throw more troops into Saint-Quentin. Given that there was no immediate prospect that it would be successfully reinforced, and despite the protection of both a moat and the river Somme, along with some very thick walls, the castle at Ham was ultimately too old-fashioned and too low-lying to withstand a modern artillery bombardment. This inherent weakness still pertained after it fell to Philip. In fact, the situation became more perilous since a significant part of Ham's defences had been reduced to rubble by the king's artillery, leaving it a sitting target. The need to repair the damage was paramount, and English sappers were assigned a central task. According to a Spanish soldier's diary, the king ordered Ham to be refortified with three caballeros, tall platforms or towers which offer forward protection to existing fortifications. The English were allotted the first tower mentioned by the chronicler. It was to be built where the moat had been drained. The intention was to prevent the French from flooding it again and drowning all those working to rebuild the defences. The chronicler pointed out that 'the English did this by working their fingers to the bone..17 It was dirty work. There was mud everywhere, he added. Sickness was taking hold in the camp and several gentlemen had already succumbed. This is confirmed by the Earl of Bedford, who was with the English contingent at Ham. On 21 September, he wrote that 'our general' was sick with an ague, which presumably was a reference not to the Duke of Savoy but to the Earl of Pembroke. ${ }^{18}$

By now it should be clear that a more nuanced account is long overdue of both the quality and the enthusiasm of the English who fought for their king in 1557. The everyday contribution of the English foot-soldiers, the cavalrymen, and their commanders has barely been commented on here even though it too deserves a thorough re-appraisal. At least it has been established that older views

17 Salvá M. - Sainz de Baranda P. (eds.), Colección de documentos inéditos para la historia de España, vol. 9 (Madrid: 1846) 541-542 [hereafter, CODOIN]. The original text says: 'este hace los ingleses a destajos'.

18 Bedford to William Cecil, Ham, 21 Sept. 1557, Calendar of the Manuscripts of the Most Hon. the Marquis of Salisbury, preserved at Hatfield House, Hertfordshire, vol. 1 (London: 1883) 144 . 
concerning an unwillingness to support King Philip need considerable modification. It is notoriously difficult to pinpoint exactly what any one military force contributed in a campaign as complicated as that of 1557. Philip's multinational army was among the largest that early modern Europeans had yet raised, numbering perhaps 50,00o men or indeed many more. Assessing what the Earl of Pembroke and his men achieved is made all the more challenging by the sad fact that sources from the English side are virtually non-existent. Infantry and commanders alike among the Spaniards, Walloons, and Germans who fought for Philip were eager to write up and often publish their version of events, just as many Frenchmen tried to salvage their reputation by putting down the sword and taking up the pen. New information that sheds light on what the English did is therefore particularly welcome. The second part of this article will offer the first and by necessity preliminary assessment of the fresh light the contemporary sketches by Antoon van den Wijngaerde cast on the role of the English.

Van den Wijngaerde the man remains mysterious. For a long time, it remained uncertain if he was one and the same as Antonio de las Viñas, or even another painter with a similar name. In Spain he is most famous for his meticulous drawings of Spanish cities. To English-speaking audiences he is known for a riverside panorama of London and various royal palaces. Wijngaerde is now assumed to have been born in Antwerp, in modern-day Belgium (but then part of the Spanish Netherlands), most probably around the year $1510 .{ }^{19}$ He died 1571, in Spain, as a 'pintor del rey'. He first served in the royal household as an artist during the reign of Charles $\mathrm{v}$. He specialised in drawing accurate pictures of cities, though the suggestion has now been made that his first battle scenes only date from the campaign of $1557 .{ }^{20}$ Interest in his legacy was renewed in 1998 when Jonathan Brown made a stunning observation. He realised that the frescos adorning the Sala de Batallas in the monastery-palace of El Escorial,

19 For the profusion of names and identities, see Galera i Monegal M. (ed.), Antoon van den Wijngaerde, pintor de ciudades y de hechos de armas en la Europa del Quinientos (Barcelona: 1998) 15, 33, 42; and, for a later date of birth, around 1525, see the outstanding catalogue, Mousset J. - L. - De Jonge K. (eds.), Un prince de la Renaissance: Pierre-Ernest de Mansfeld (1517-1604), vol. 2: Essais et catalogue (Luxembourg: 2007) 418-429 and 8284. It contains Pieter Martens's initial analysis of the relationship between the works of Wijngaerde and his son-in-law. Martens has since taken his comments further in his chapter, "Cities under Siege Portrayed ad vivum in Early Netherlandish Prints (1520-1565)", in Balfe T., Woodall J. - Zittel C. (eds.), Ad vivum?: Visual Materials and the Vocabulary of Life-Likeness in Europe before 1800 (Leiden - Boston: 2019) 151-199. I am indebted to Dr. Martens for providing me with a copy of "Cities Under Siege" as this chapter was going to print.

See Martens, "Cities Under Siege” 171. 
and which depict the campaign of 1557 , ultimately derived from engravings that Wijngaerde had made and even published soon after the campaign finished. Since many who had been present at the battle were still alive, there was a clear commercial motive for a high degree of topographical accuracy in Wijngaerde's depictions. This explains why the Italian painters who worked on the Sala in the 159os were instructed to copy faithfully the paintings of the campaign already produced by Rodrigo de Holanda. Rodrigo de Holanda (or Diriksen) was Wijngaerde's posthumous son-in-law, and Brown's reasoning was that:

[...] in all probability, the source used by Rodrigo de Holanda was an engraving by his father-in-law, Anton van der Wyngaerde, who had been present at the battle in the service of Philip II. Similarly he was able to make use of other engravings by the same artist, to depict the fall of the fortresses of Le Catelet and Ham. ${ }^{21}$

I wish to take Brown's thesis further and reformulate it by saying that the frescoes in El Escorial, thanks in the main to their reliance on Rodrigo de Holanda, are to all intents and purposes faithful not just to the engravings. They are also faithful to the compositions which Wijngaerde made while he was present during the hostilities and which have only recently begun to merit the attention they deserve. That is to say, because Wijngaerde's engravings which he produced commercially in the Low Countries shortly after the great victories at Saint-Quentin are so closely based on his original sketches, we can just as well say that both the frescos in El Escorial and the earlier engravings were effectively inspired by the ink and watercolour sketches which Wijngaerde drew on site in August and September $1557 .{ }^{22}$ Of course, further aesthetic

21 Brown J., La sala de batallas de El Escorial: La obra de arte como artefacto cultural (Salamanca: 1998) 43: 'Sin embargo, con toda probabilidad, la fuente utilizada por Rodrigo de Holanda fue un grabado de su suegro, Anton van der Wyngaerde, que había presenciado la batalla al servicio de Felipe II. También pudo disponer de otros grabados del mismo artista, para representar las tomas de las fortaleza [sic] de Le Catelet y Ham'.

22 In this sense, I also go beyond the views of Carmen García-Frías Checa. In 2006 she argued only that (my italics) 'se puede suponer que posiblemente Rodrigo tuvo la oportunidad de utilizar para la composición de sus famosos disinios y lienços los dibujos originales que Wijngaerde había realizado de la guerra', in her wide-ranging essay, "Las series de batallas del Real Monasterio de San Lorenzo de El Escorial. Frescos y pinturas", in García García B.J. (ed.), La imagen de la guerra en el arte de los antiguos Países Bajos (Madrid: 2006) 135-169, here 141, where she also talks only of 'una estrechísima relaçión' between Wijngaerde's drawings and engravings with Holanda's paintings (some of which remain in El Escorial) as well as with the frescos. In addition to putting flesh on the relationship 
research will almost certainly reveal more substantial differences and perhaps omissions in the later reformulations, but from a historical point of view the depictions of the campaign we have at El Escorial, and the many related engravings which have survived, are reformulations of original and contemporary battlefield sketches. By whatever route, the frescos at El Escorial lead us squarely back to the events of late summer in 1557. That all these representations have the imprimatur of the person who commissioned them, another eyewitness - that stickler for detail, King Philip - is but icing on the cake.

The result is that we are able to take the visual evidence of Wijngaerde's sketches as meaningful representations of what actually happened. In fact, the materiality of the way in which these drawings were put together underlines their accuracy. ${ }^{23}$ They comprise one or more large sheets of paper, presumably because a larger format was necessary to do justice to the topographical panorama before him. They have come down to us in varying stages of composition. As we can see from his preliminary sketch for the siege of Le Catelet, one of the five originals from 1557 preserved in Antwerp, it would appear that Wijngaerde's method of operation was to produce a topographically accurate outline of the site and then to add a brief note stating which commander and what type of troops and how many were stationed on that spot. ${ }^{24}$

Part of his genius was an ability to translate what he saw into a bird's-eye view. This is evident in the two Antwerp sketches of the battle and siege of

between Holanda and his father-in-law, García-Frias's article remains invaluable for listing Wijngaerde's works. Nonetheless, given the present state of knowledge, it is not possible to say which (or indeed if any) of his father-in-law's drawings, extant or otherwise, Holanda may have had access to, that is besides any engravings or lost paintings by Wijngaerde.

23 As Martens confirms, the reason for 'the long afterlife' of Wijngaerde's drawings 'was precisely their authority as first-hand records', "Cities Under Siege” 189. For Martens's view of how the drawings were made, 182.

24 "The Assault on Le Catelet" [Beleg van Le Châtelet], being now conserved at the Museum Plantin-Moretus in Antwerp (Рк.от.о1171); the five others are "The Battle of SaintQuentin" [Slag bij Saint-Quentin] (Рк.от.о1168); "The Assault on St.-Quentin" [Beleg van Saint-Quentin] (Рк.от.o1167), reproduced here as Fig. 1.1; "The March on Ham” [Spaanse troepen op weg naar Hain] (PK.T.o1169), reproduced here as Fig. 1.2. The Victoria \& Albert Museum in London also holds a sketch of the events at Ham, va 41 (also known as item 8455:21), which is catalogued under 'Wyngaerde' and called 'Panoramic View of Picardy, with the Siege of Ham'. (In addition, Antwerp also possesses a sketch from later in Philip's war, the $155^{8}$ March on Doullens Рк.от.o1170). The staff of the Victoria and Albert Museum in London were most helpful, as were the staff of the Plantin-Moretus Museum in Antwerp, in particular Mr. Jan de Bruyn and Ms. Virginie D'haene. In addition to the two reproductions in this volume, each of these sketches is available as zoomable high-resolution images on the relevant websites, and these images are also reproduced in Moussset - De Jonge, Un prince de la Renaissance. 


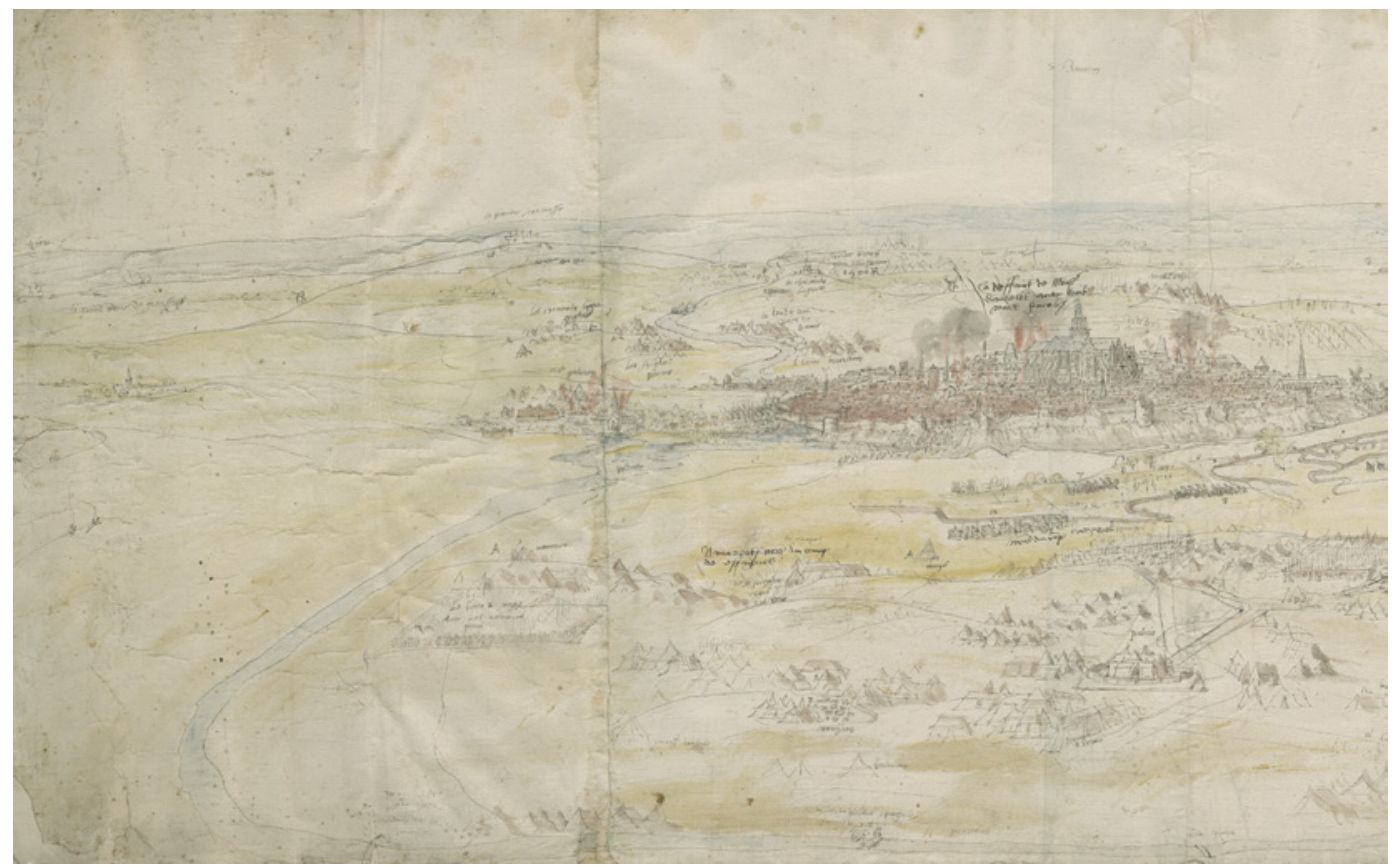

FIGURE 1.1 Antoon van den Wijngaerde, “The Assault on St.-Quentin” [Beleg van Saint-Quentin]. The three English encampments are on the left-hand side of the image, over the river from Saint-Quentin.

Saint-Quentin, where he chooses to adopt two different angles of sight. Of course, we should not believe that he is taking 'photographs' of the campaign. Just as with a written chronicler, he incorporates what he saw with what he learnt subsequently from other eyewitnesses, which is particularly obvious from his depiction of the Battle of Saint-Quentin. He includes in one drawing the three stages of the battle, each of which occurred at slightly different locations: the French attempt to throw in troops through the wetlands to the west of the town; the Duke of Savoy's decision to outflank them from the east; and finally the battle as the French headed towards the safety of woods to the south.

Wijngaerde's original sketches and what they spawned have much more to tell us. There is space here only to begin an examination of the visual evidence they provide in order to support and to challenge what we know from the written record: first to supplement what we now know concerning English involvement in the attack on Ham; and finally to return to fundamental questions about the role played by King Philip's English army in the storming of Saint-Quentin.

England's contribution to the campaign of 1557 was inevitably going to be limited, at least in terms of a strictly military contribution. Her army was 


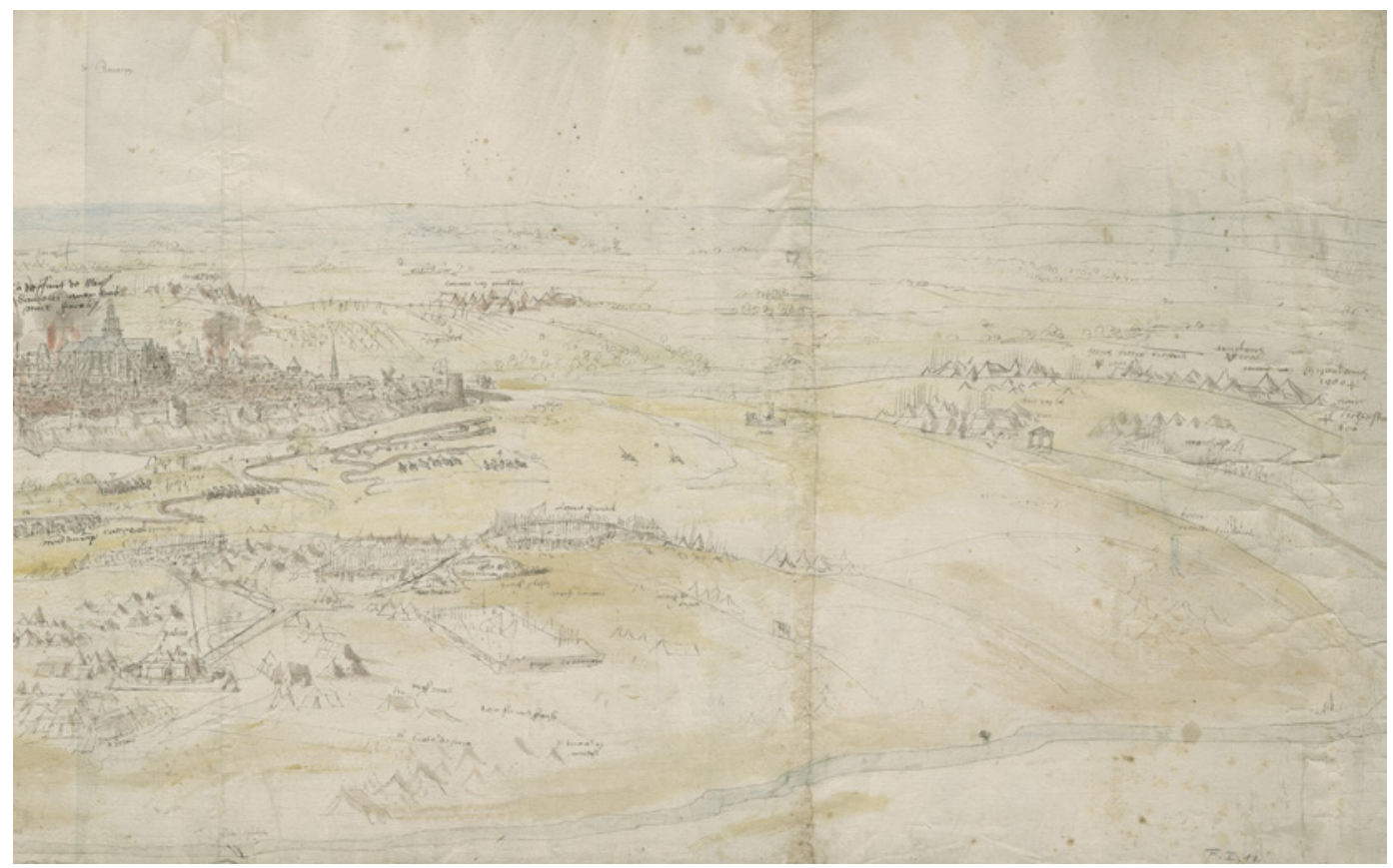

PK.OT.01167. Drawing, $115 \times 43 \mathrm{~cm}$. Collectie Stad Antwerpen, Museum Plantin-Moretus (Printroom Collection) PUBLIC DOMAIN

quasi-medieval, with individual members of the nobility volunteering with their retinue to serve abroad. It was intended for mid-summer fighting and not the year-after-year service expected of Spanish professionals or German mercenaries. In addition to their admittedly formidable archers, the English combatants were armed not with the latest in guns but largely with long wooden bills and pikes. Crude if time-honoured, these weapons still had an important role to play, especially in close combat where firearms might prove slow or inaccurate. The English also brought with them 12 pieces of probably mediumsized cannon, which - on a strictly numerical basis - would have increased the number of artillery pieces at the king's disposal by over $16 \% .{ }^{25}$ But the English also brought with them soft power. After succeeding his father as ruler of the Spanish monarchy, Philip needed to show at the commencement of his reign that he was a worthy successor to a proven warrior. An ability to demonstrate that he could wield real power or influence over his wife's kingdom was a necessary part of proving his virility as a ruler. Though the English had achieved little in France since the beginning of the fifteenth century, the historical memory

25 For an estimation of the combined forces, see Lemaire, La guerre de $1557312-315$, here 315. 


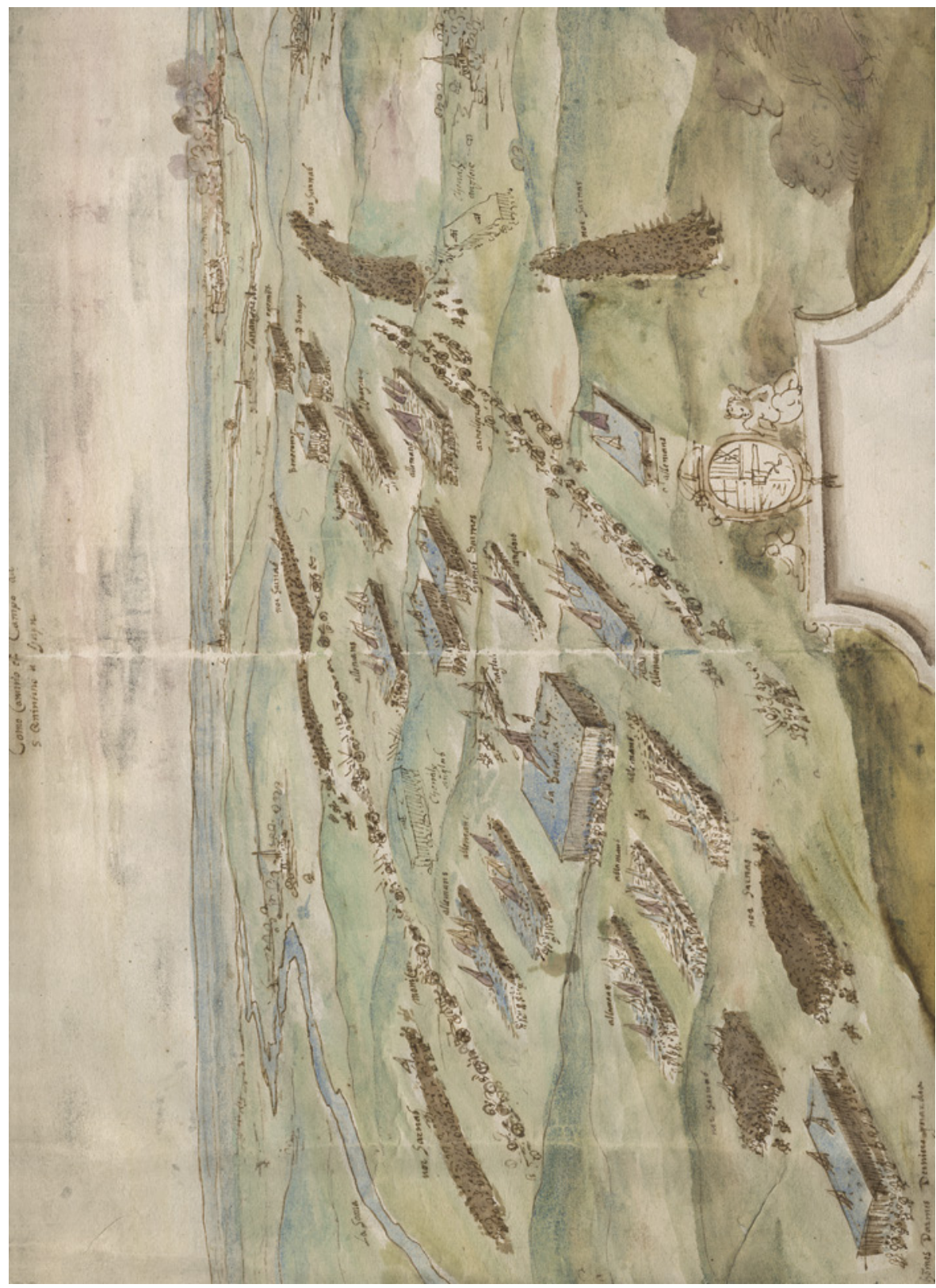

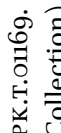

实

๘

สี

$\mathbb{D}^{\circ}$

के छे

:

$\nsubseteq$.

䨌

政

踣

की

"घ द्ञ

苂

ธี

돈

$\sum_{0}^{\pi} \frac{\pi}{\infty}$

\&

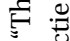

एृ

๑

क्ष

今

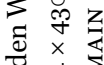

吉方

त्र

b.

造

N

곤 
of their prowess and their violence in the 100 Years' War remained strong, not least thanks to Froissart and his ever-popular chronicles. It therefore comes as no surprise that, after his arrival on the banks of the Somme, it was English archers whom Philip chose to fire arrows into the town with a message attached calling on its inhabitants to surrender to their rightful king. ${ }^{26}$

Wijngaerde's sketch of the March on Ham is essential for grasping how much the English contributed in terms of soft power. All that the written sources tell us is that at dawn on 8 September the Duke of Savoy left the foul-smelling ruins of Saint-Quentin for Ham, with all the infantry and cavalry, 'apart from the English and some Germans who stayed behind in order to go with His Majesty'. ${ }^{27}$ Wijngaerde puts pictorial flesh on this bald statement. Surrounded by a massive phalanx of bodyguards, the king is advancing on Ham at the centre of all his troops. ${ }^{28}$ Five units ahead is the vanguard, fittingly led by the Count of Egmont, the hero of the battle of Saint-Quentin, and behind him is the Duke of Savoy followed by a row of Spanish troops and another of various professional men-at-arms. Immediately preceding the king, both to his right and left, are two companies of English footmen. They have the place of honour. A little further to the side, his flanks are guarded by two detachments of English cavalry. How far this depiction is literally true may be debated. It is indeed curious that the English cavalry, uniquely, are not coloured in, yet this does not necessarily make them a later pictorial addition. This is because, if the space allotted to them had originally been intended to be left blank, this would have left the king, according to the configuration set out by Wijngaerde, dangerously exposed on each flank. Regardless of how later historians have argued over the competence of the English army at Saint-Quentin, the visual evidence suggests that King Philip continued to believe that their presence was invaluable. Perhaps it was a reward. Just a few days before the remove to Ham, at the storming of St. Quentin, the Spaniard, Juan de Pinedo, penned a note while moppingup operations were going on. Everyone, he said, had fought most choicely but the English above all! ${ }^{29}$ The second and final illustration of how we can use visual evidence leads us back to the great army that had besieged Saint-Quentin.

26 For this incident and the placing of the campaign in the context of Philip's rule in England, see Redworth G., "Matters Impertinent to Women: Male and Female Monarchy under Philip and Mary", The English Historical Review CXII, 447 (1997) 597-613.

27 'menos los ingleses y algunos alemanes que quedaron para ir con S.M.', CODOIN, IX 534.

28 "Spaanse troepen op weg naar Hain" (Р к.от.o1169). See Fig. 2.

29 'muy es cogidam[en]te todos / y [interlineated] por estremo. Los ingleses. -', Archivo General de Simancas, Juan de Pinedo to Spanish ambassador to Venice, Estado-K, 149o, fol. 77a. Two thousand English troops were ordered to join with 400 seasoned Spanish infantrymen and 3 companies of Burgundians in a head-on attack on the town's principal gate, where the greatest number of casualties occurred. 
The deployment of the Earl of Pembroke's troops has never been properly investigated, although it is fundamental for determining how were they regarded in terms of both hard and soft power. Were they relegated to an obscure corner of the battleground? Somewhere where their attendance would be seen, yet without strategic significance? Was their sole use to serve as cannon fodder, to protect more experienced and proficient troops?

Born around 1591, already some thirty years after the fighting, Quintin de La Fons came from an established saint-quentinoise family. He was a canon of the great basilica dedicated to the Roman martyr, St Quentin, who gave the town its name. The churchman became the town's pre-eminent chronicler. He was adamant that the English were stationed a little to the west of the town, near St Martin's gate, between the chapel d'Epargnemaille and Rocourt, which is to say north of the river Somme and the extensive marshland surrounding the town both to the south and west. ${ }^{30}$ His account seems implausible for two reasons. First, given that the presence of the English army had become indispensable to Philip's insistence that he be acknowledged as an effective King of England, it is highly probable that the English not only escorted him on 13 August to what became his headquarters on the east of the town but that they also remained in relative close proximity to him, at least for the first few days, that is until they were ordered to relocate on the 22nd. Second, the western approaches to the town were never fully invested, perhaps because they had been discovered to be too waterlogged and topographically unsuitable for positioning heavy artillery batteries. Written sources tell us that the English had been ordered to position themselves to the south of the Somme. They were to

leave their lodgings for the part of the lake where yesterday the French tried to get in [to the town] using boats, and this was done to strengthen defences there against any type of help of relief that could come from there. ${ }^{31}$

The English were moved in response to a frantic attempt by the French to cross the swamps at night. Although innumerable of their soldiers were captured or

30 La Fons Q. de, Extraits originaux d'un manuscrit de Quentin de La Fons intitulé histoire particulière de l'église de Saint-Quentin: Publiés, pour la première fois, ed. C. Gomart, vol. 2 (Saint-Quentin: 1856), 71.

31 CODOIN IX 5 O1. The date given for the assault is 20 August at 1 o'clock in the morning. 
drowned, it was estimated that two hundred reinforcements had nonetheless managed to enter the town. ${ }^{32}$ In other words, Philip had sufficient trust in his English soldiers to order them to seal off a weak point in the encirclement of the town. It follows that the English must have been initially camped in a place from where they could move rapidly to secure the weak spot on the left bank of the river. Either the English were already encamped on the south side, or more probable were still with the king on the eastern side of the town, because the only feasible means for large numbers of troops to cross the river was, indeed, to the east. ${ }^{33}$

The definitive answer as to where King Philip placed his English army is surely provided by Wijngaerde. His sketch of the assault emphatically places the English forces to the south of the river, in the hills rising up from the eastern part of modern-day Gauchy, perhaps rising up from around an area now known as La Biette. ${ }^{34}$ This was a highly strategic position. The English infantry was closest to the river, defending the light cavalry above them, who in turn were protecting the English artillery placed highest of all. It made perfect sense that their military next-door-neighbour would have been Captain Julián Romero. For many years had served as a mercenary in England and liked to believe that he had been knighted by Henry VIII. ${ }^{35}$ Fanciful though it may seem, one can even see - but only if one has a mind to - that Wijngaerde has drawn a flag of St George atop the English gun emplacements. More prosaically, Gauchy was an ideal place to position Englishmen who were eagerly awaiting the king's final order to make the relatively short journey to attack, head on, the town's southern and heavily fortified gate. After all, their captains had gone to the king to ask him face-to-face to grant them this honour.

The great nineteenth-century American historian, William H. Prescott, was no Englishman but he was an anglophile and a Protestant to boot. His view of England's involvement in the campaign of 1557 shared many of the prejudices of Sir John Fortescue, whose words opened this essay. Prescott said that the English were 'discontented'. They brought 'from home the aversion for

\footnotetext{
$32 \quad$ CODOIN IX 498.

33 For the difficulties in crossing the river, see Oman C., A History of the Art of War in the Sixteenth Century (London: 1937) 257 and n.1.

34 "The Assault on St.-Quentin" [Beleg van Saint-Quentin] (Рк.от.on67). See Fig. 1.

35 Romero's career has been meticulously documented by Fagel R.P., Kapitein Julián: de Spaanse held van de Nederlandse Opstand (Hilversum: 2011). Professor Fagel generously provided me with a copy of his book. For Romero's career in England, see 16-21.
} 
the Spaniards which had been festering there since the queen's marriage. The sturdy islanders were not at all pleased with serving under Philip. They were fighting, not the battles of England, they said, but of Spain. ${ }^{36}$ The evidence, both written and visual, no longer supports such a view. Philip and Mary's reign is increasingly seen in a more positive light. The failure to perpetuate Catholicism as the national religion is now viewed as the result of the queen's premature death rather than from a structural weakness within the regime. No one is saying that England's quasi-feudal army tipped the balance in favour of King Philip's victory in 1557. Yet perhaps the unpalatable truth for some is that, 500 years ago, the English were prepared to accept a European destiny.

\section{Bibliography}

\section{Primary Sources}

British Library London (= BL)

Stowe Ms. 571

Stowe Ms. 572

Calendar of State Papers Spanish, ed. R. Tyler, 13 vols. (London: 1862-1954).

Nichols J.G. (ed.), The Diary of H. Machyn, Citizen and Merchant Taylor of London, from $A D 1550$ to $A D$ 1563, Camden Society 42 (London: 1848).

Real Biblioteca, Madrid (= RBM)

Ms. II-2289

Ms. II-2549

Salvá M. - Sainz de Baranda P. (eds.), Colección de documentos inéditos para la historia de España, 112 vols. (Madrid: 1842-1896).

Wriothesley C., A Chronicle of England during the Reigns of the Tudors, from A.D. 1485 to 1559, ed. W.D. Hamilton, 2 vols. (London: 1875-1877).

\section{Secondary Sources}

Adams S., "The Dudley Clientele", in Bernard G.W. (ed.), The Tudor Nobility (Manchester: 1992) 247-253.

Balfe T. - Woodall T. - Zittel C. (eds.), Ad vivum?: Visual Materials and the Vocabulary of Life-Likeness in Europe before 1800 (Leiden - Boston: 2019).

36 Prescott W.H., History of the Reign of Philip the Second, King of Spain, vol. 1 (London: 1855) 204. I wish to record my gratitude to the members of the Société academique de Saint-Quentin, and to its president, Mme. Maryse Trannois, for their extraordinary kindness and assistance during my stay in Saint-Quentin. I am also grateful to Professors Peter Wilson, Hamish Scott, Paulina Kewes for their comments, along with those of Drs Christopher Henstock and Jenni Hyde. 
Bernard G.W. (ed.), The Tudor Nobility (Manchester: 1992).

Brown J., La sala de batallas de El Escorial: La obra de arte como artefacto cultural (Salamanca: 1998).

Calendar of the Manuscripts of the Most Hon. the Marquis of Salisbury, preserved at Hatfield House, Hertfordshire, 24 vols. (London: 1883-1976).

Davies C.S.L., "England and the French War, 1557-9", in Loach J. - Tittler R. (eds.), The Mid-Tudor Polity, c. 1540-156o (London: 1980) 159-185.

Fagel R.P., Kapitein Julián: de Spaanse held van de Nederlandse Opstand (Hilversum: 2011).

Fortescue Sir J.W., A History of the British Army, 2nd ed. (London: 1910).

Galera i Monegal M. (ed.), Antoon van den Wijngaerde, pintor de ciudadesy de hechos de armas en la Europa del Quinientos (Barcelona: 1998).

García-Frías Checa C., "Las series de batallas del Real Monasterio de San Lorenzo de El Escorial. Frescos y pinturas", in García García B.J. (ed.), La imagen de la guerra en el arte de los antiguos Países Bajos (Madrid: 2006) 135-169.

Hammer P., Elizabeth's Wars: War, Government and Society in Tudor England, 1544-1604 (Basingstoke: 2003).

Kervyn de Lettenhove J.M.B.C. (ed.), Relations politiques des Pays-Bas et de l'Angleterre, 11 vols. (Brussels: $1882-1900)$.

La Fons Q. de, Extraits originaux d'un manuscrit de Quentin de La Fons intitulé histoire particulière de l'église de Saint-Quentin: Publiés, pour la première fois, ed. C. Gomart, 3 vols. (Saint-Quentin: 1854-1856).

Lemaire E. et al., La Guerre de 1557 en Picardie: bataille de Saint-Laurent, siège de Saint-Quentin, prises du Catelet, de Ham, de Chauny et de Noyon (St.-Quentin: 1896).

Loach J. - Tittler R. (eds.), The Mid-Tudor Polity, c. 1540-156o (London: 1980).

Loades D., The Reign of Queen Mary: Government, Politics and Religion 1553-58, 2nd ed. (Abingdon: 2013).

Martens P., "Cities under Siege Portrayed ad vivum in Early Netherlandish Prints (15201565)", in Balfe T. - Woodall T. - Zittel C. (eds.), Ad vivum?: Visual Materials and the Vocabulary of Life-Likeness in Europe before 1800 (Leiden - Boston: 2019).

Mousset J.L. - De Jonge K. (eds.), Un prince de la Renaissance: Pierre-Ernest de Mansfeld (1517-1604), 2 vols. (Luxembourg: 2007).

Oman Sir C., A History of the Art of War in the Sixteenth Century (London: 1937).

Prescott, W.H., History of the Reign of Philip the Second, King of Spain, 2 vols. (London: 1855).

Redworth G., "Matters Impertinent to Women: Male and Female Monarchy under Philip and Mary", The English Historical Review CXII, 447 (1997) 597-613.

Rodríguez-Salgado, M.J. The Changing Face of Empire: Charles V, Philip II and Habsburg Authority (Cambridge: 1988). 